\title{
MTA1 wt Allele
}

National Cancer Institute

\section{Source}

National Cancer Institute. MTA1 wt Allele. NCI Thesaurus. Code C92516.

Human MTA1 wild-type allele is located in the vicinity of $14 q 32.3$ and is approximately 50 $\mathrm{kb}$ in length. This allele, which encodes metastasis-associated protein MTA1, is involved in the regulation of gene transcription that may be the result of binding to the estrogen receptor or remodeling of chromatin. 